\title{
The predictors of Indonesia's palm oil export competitiveness: A gravity model approach
}

\author{
Ira Eka Pratiwi \\ International Development and Cooperation, \\ Graduate School of Pan-Pacific, Kyung Hee University, \\ South Korea \\ pratiwi.iraeka@,kbu.ac.ker \\ ORCID 0000-0002-3583-4094
}

Abstract. Indonesia, the largest palm oil-producing country, has a great potential to market this product domestically and internationally. Thus, the important factors that affect exports must be considered to maintain palm oil as the comparative advantage and major export commodity in the global market. This study aims to analyze Indonesia's palm oil export competitiveness in selected leading destination countries, including China, the United States, India, the Netherlands, and Spain, and to identify the determinant that affected the export of palm oil from Indonesia to the selected main partner countries for 2000 - 2019 by means of gravity model approach. The methods used in this study is the Revealed Competitiveness Advantage (RCA) Index and panel data regression. This study finds that Indonesia's palm oil export is strongly competitive in main partner countries, namely the United States, China, India, the Netherlands, and Spain. Furthermore, the substantial predictors of Indonesia's palm oil export are economic distance, real GDP per capita of partner countries, Free Trade Agreement (FTA), Non-Tariff Measurements (NTMs), and real exchange rate. Therefore, the gravity model used in this study indicates no essential barriers limiting the export of Indonesia's palm oil to main destination countries. Furthermore, there is a need for Indonesia to strengthen its bilateral cooperation and trade diplomacy.

Keywords: revealed competitiveness advantage, trade, non-tariff, exchange rate.

JEL Classification: C23, F13, F14 


\section{INTRODUCTION}

Nowadays, globalization occurs in countries through international trade. Thus, it has caused an increase in the dependent relationship between nations. Two countries participate in international trade through export and import activities. A country benefits from these activities, such as fulfilling its society's necessity for importing activities, gaining higher income, and expanding its commodities market for exporting activities. That is why international trade allows countries to specialize in producing goods efficiently, to increase efficiency and production scale. This explanation is first described by David Ricardo with his theory of "Comparative Advantage". Therefore, a country needs to create trading strategies related to a commodity with competitiveness in international trade.

As a developing country, Indonesia has abundant natural and human resources, potentially benefiting its economic development. However, Indonesia is still allegedly not maximizing the potential for its growth and welfare. Wardani et al. (2018) state that Indonesia should create a comprehensive strategy to improve its trade performance since there is high competition in international trade between countries.

As an agricultural country, Indonesia can boost its economic growth through international trade in the agricultural sector. The Indonesian Center of Statistics Bureau stated that in 2018 the contribution of the agricultural sector in Indonesia Gross Domestic Product (GDP) was around 12.81 per cent. Therefore, this sector has an essential role in the economic activity in Indonesia. Meanwhile, one of the considerable potential sub-sectors in Indonesia's agricultural industry is the plantation sector, contributing to Indonesia's total GDP by around 3.30 per cent in 2018 .

The palm oil industry is an essential component of the national economic and agricultural sector, especially as a foreign exchange source (Yulismi \& Siregar, 2007). As the largest palm oil-producing country globally ${ }^{1}$. Indonesia has great potential to market this product both domestically and internationally. Several central destination countries for marketing palm oil in Indonesia are China, India, the United States, the Netherlands, and Spain. Figure 1 depicts Indonesia's palm oil exports to the selected major countries, which shows some fluctuations in palm oil export to the five major countries destination during $2012-2019$. The latest data from Statistics Indonesia also gives information that during the pandemic of COVID-19 in 2020, the palm oil export to India, the US, and Spain experienced an increase, while to China and the Netherlands, there was a decline compared to the previous year. Since the pandemic still exists in 2021 and its end is unpredictable, there may be different development scenarios for Indonesia's palm oil export in the following years. Therefore, this paper aimed to analyze Indonesia's palm oil export competitiveness in the selected leading destination countries, including China, the United States, India, the Netherlands, and Spain, using the Revealed Competitiveness Advantage (RCA) Index.

The objectives of the research are as follow:

1. To measure the competitiveness of Indonesia's palm oil export in the main destination countries, including India, China, the USA, the Netherland, and Spain.

2. To identify the essential factor that affected the export of palm oil from Indonesia to main destination countries.

In this study, we calculated Indonesia's palm oil export comparative advantage to the five main importing countries. We employ the Revealed Comparative Advantage (RCA) index to estimate the competitiveness and investigate the determinant of Indonesia's palm oil export to the main destination countries. Based on our knowledge, there is no previous study evaluating Indonesia's palm oil export competitiveness focusing on these five major importing countries. Thus, the essential factors that affect

\footnotetext{
${ }^{1}$ Market Brief of Palm Oil and Its Processed, Ministry of Trade of The Republic of Indonesia, 2013.
} 
exports must be considered to maintain palm oil as the comparative advantage and major export commodity in the global market.

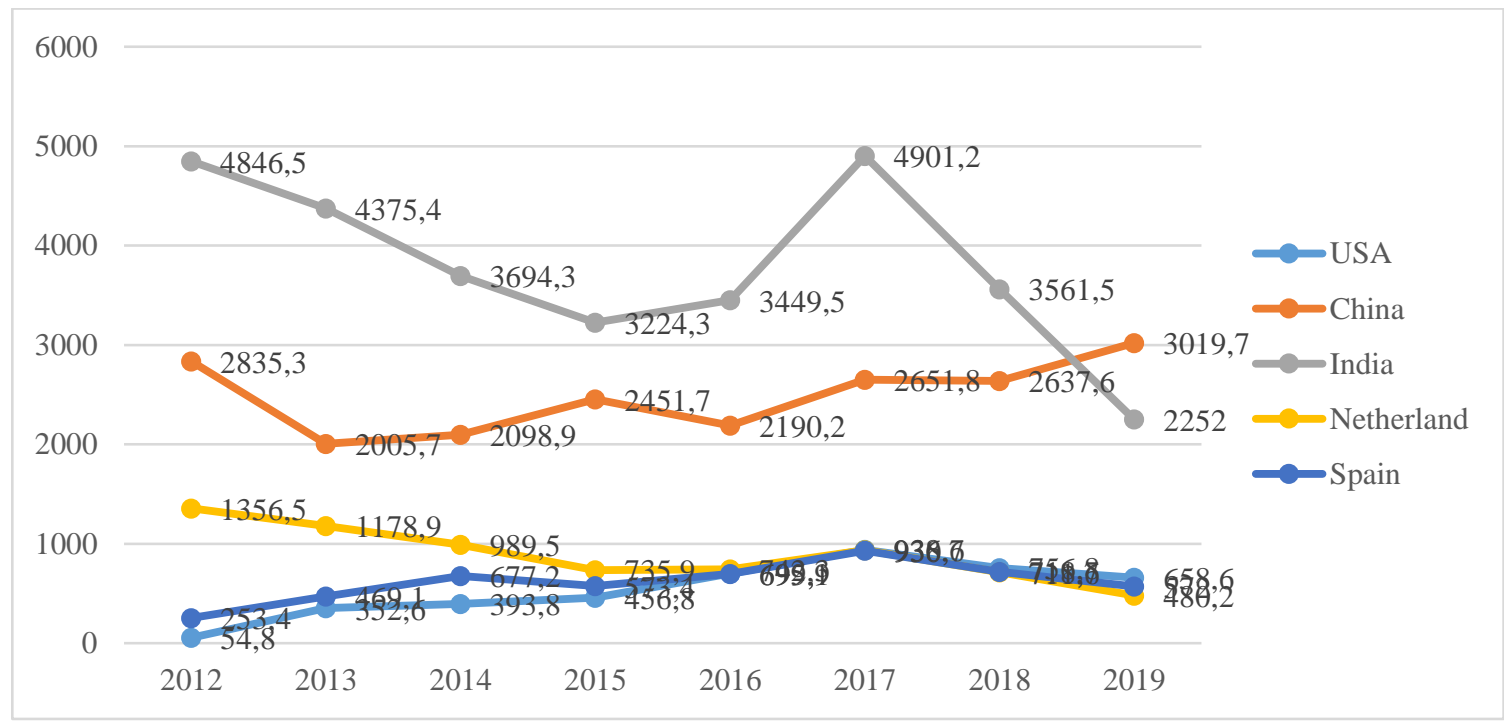

Figure 1. Export Value of Palm Oil of Indonesia to Five Main Destination Countries (Millions US \$)

Source: Statistics Indonesia (BPS, 2021)

\section{LITERATURE REVIEW}

Why should a country trade? The theory of comparative advantage can explain the answer in international trade postulated by David Ricardo (1817). In his theory, Ricardo mentioned that countries would gain benefits from trade. Land might be more productive in making any goods by using fewer inputs, such as capital and labour than other countries produce the same goods. However, comparative advantage explained that a country would produce a good that could benefit more by exporting the good and importing the other goods from another country. For example, although a country is twice as productive as its trading partners in making good A, if it is three times as productive in good B, it would benefit from producing and exporting good B and importing good A. As a result, its partner will gain by exporting good A-with comparative advantage (McDonald, 2009).

\section{The determinant of International Trade specifically Export}

According to UNCTAD (United Nation Conference on Trade and Development, 2005), the export performance of a country is determined by several factors:

1. Domestic Transport Infrastructure

2. The real exchange Rate

3. Foreign Direct Investment

4. Institution

Branson (1981) assumed that the export demand was influenced by the interest rate and real foreign exchange rate in exporter countries. In addition, according to (Bahmani-Oskooee (1986), the world demand for a country's aggregate export is determined by the real GNP of a country's trading partners, export price, export prices of a country's trading partners, and exchange rate. In their research, Yee et al. (2016) concluded 
that export is influenced by several factors, including foreign exchange rate, inflation of the export country, FDI (Foreign Direct Investment), and import.

\section{The gravity model}

According to the gravity model, there will be a correlation between the size of the population and the distance on the volume of spatial interaction among countries, regions, cities, or places. When the number of people of two countries is large, it can be assumed that the volume of interaction between two countries tend to be large, or there is a positive relationship between population size and volume of interaction between two countries. However, if the two countries have long distances, then the volume of interactions may decline. The gravity model is written as follows (Wheeler, 2005):

$$
I_{i j}=k\left(\frac{P_{i} \cdot P_{j}}{D_{i j}^{b}}\right)
$$

Meanwhile, the gravity model has been widely used in international trade studies to identify the country's determinants of trade flows. The model is based on Newton's theory of the universal law of gravitational in physics, i.e. the gravitational attraction between two objects is based on their size or masses and related to their distance (Dinh, Nguyen dan Hoang, 2011). Therefore, according to this model, the trade between countries depends on their size and is inversely related to their distance.

Krueger (2000), in his study, used the gravity model to investigate the trade creation and trade diversion under the North America Free Trade Agreement (NAFTA) by implementing several variables such as export value, the income of the export country and import country, distance between the export country and import country, population in the export country and import country (Hapsari dan Mangunsong, 2006).

In this paper, we used the gravity model with several modification by adding new variables, including inflation of the export country, foreign direct investment of export country, real foreign exchange rate, free trade agreement (FTA), the common boundary between the export and import country, the same language between the export and import country.

\section{METHODOLOGY}

The secondary data used in this study consist of time series data from 2000 to 2019 and the crosssectional data of Indonesia's palm oil export to several main trader partner countries, including China, India, the USA, Spain, and the Netherland. Meanwhile, the data was analyzed with two methods; RCA (Revealed Comparative Advantage) Index and panel data processing. Data were collected from several institution websites, such as the United Nations Commodity and Trade (UNCOMTRADE), the World Bank, and the Central Bank of Indonesia.

Revealed Comparative Advantage (RCA) is a common method used as a measurement to calculate trade competitiveness. The formulation of RCA is as follows:

Where,

$$
R C A=\left(X_{i j} / X_{j}\right) /\left(X_{w i} / X_{w}\right)
$$

$\mathrm{X}_{\mathrm{ij}}=$ the export value of commodity $i$ by country $j$

$\mathrm{X}_{\mathrm{j}}=$ the value of total export by country $j$

$\mathrm{X}_{\mathrm{wi}}=$ the world exports value of commodity $i$

$\mathrm{X}_{\mathrm{w}}=$ the value of total world export 
The score of the RCA Index determines the comparative advantage of the country. If the RCA index for a certain commodity is larger than 0 but smaller than $1(0<\mathrm{RCA} \leq 1)$, the country has no comparative advantage. If the RCA index is $1<\mathrm{RCA} \leq 2$, then there is a weak comparative advantage. And, if the value of the RCA index is $2<\mathrm{RCA} \leq 4$, then there is a moderate comparative advantage. Meanwhile, if the RCA is larger than $4(\mathrm{RCA}>4)$ then there is a strong comparative advantage (Hinloopen dan Van Marrewijk, 2001).

Meanwhile, analysis of the factors influencing the export of Indonesia palm oil to the main trading partner countries was carried out by using the panel data regression, which consists of variables referring to the gravity model with some additional variables. The export value of Indonesia palm oil (EXP) becomes the dependent variable. In contrast, the independent variables consist of Foreign Direct Investment (FDI), Population of the importing country (PPX), Economic Distance between Indonesia and importing country (DIS), common boundary shared by Indonesia and the importing country (BOR), the same language speak by Indonesia and the importing country (LAN), Exchange Rate of importing countries (ER), Inflation of importing countries (INF), Free Trade of Agreement between Indonesia and Importing countries (FTA), GDP of Destination Countries (GDPX), and Non-Tariff Measurements imposed by the importing countries (NTM). The specific model of the analysis can be made as follows:

$$
\begin{gathered}
\operatorname{lnEXP} \operatorname{sP}_{j t}=\mathrm{b}_{\circ}+\mathrm{b}_{1} \mathrm{PPX}_{j t}+\mathrm{b}_{2} \mathrm{DIS}_{j j t}+\mathrm{b}_{33 \operatorname{lnFD} j t}+\mathrm{b}_{4} \operatorname{lnER} \mathrm{R}_{i t}+\mathrm{b}_{5} \mathrm{BOR}_{i j}+\mathrm{b}_{6} \mathrm{LAN}_{i j}+\mathrm{b}_{7} \mathrm{FTA}_{j t}+\mathrm{b}_{8} \operatorname{InGDPX}_{j t}+ \\
\mathrm{b}_{9} \mathrm{NTM}_{j t}+\mathrm{b}_{10} \mathrm{INF}_{j t}+e_{j t}
\end{gathered}
$$

Where:

$\operatorname{EXP}_{j t} \quad$ : The export value of Indonesia palm oil to country $j$ in year $t$ (US\$)

$\operatorname{PPX}_{j t} \quad:$ The population size of country $j$ in year $t$

DIS $_{i j} \quad:$ The economic distance between Indonesia and country $j$

$\mathrm{FDI}_{t} \quad:$ The foreign direct investment of country $j$ in year $t$

$\mathrm{ER}_{\text {it }} \quad$ : The exchange rate of Indonesia currency in year $t$

$\mathrm{INF}_{\text {it }} \quad$ : The inflation rate of country $j$ in year $t$

$\mathrm{BOR}_{i j} \quad$ : Dummy variable whether the country share a common boundary. If Indonesia and country $j$ shared the same border, then the value is equal to 1 . But if Indonesia and country $j$ do not share the same border, then it is valued 0 .

$\mathrm{LAN}_{i j} \quad$ : Dummy variable whether the country speak the same language. If Indonesia and country $j$ used the same language, then the value is equal to 1 . But if Indonesia and country $j$ do not use the same language, then it is valued 0 .

FTA $_{j t} \quad$ : Dummy variable for free trade agreement (FTA) between Indonesia and country $j$ in year $t$. If the there is FTA between Indonesia and country $j$ then the value is equal to 1 . However, if there is no FTA between Indonesia and country $j$, then the value will be equal to 0 .

GDPX $_{j t} \quad$ : GDP per capita of import country $j$ in year $t$

NTM $_{j t}$ : Dummy variable for Non-Tariff Measurements (NTM) between Indonesia and country $j$ in year $t$. If the there is NTM between Indonesia and country $j$ then the value is equal to 1 . However, if there is no NTM between Indonesia and country $j$, then the value will be equal to 0 .

bo $\quad$ : intercept

$b_{1}, b_{2}, . ., b_{9}:$ coefficient of the regression of each independent variables

$e_{j t} \quad$ : error term 


\section{EMPIRICAL RESULTS AND DISCUSSION}

Based on the calculation result of the Revealed Comparative Advantage (RCA) indices from 2000 until 2019, shown in Table 1, Indonesia generally experiences strong comparative advantages of palm oil export in five major importing countries, namely the United States, China, India, the Netherlands, and Spain which is greater than 4. During this period, the RCA indices are larger than 4, indicating that Indonesia has a strong comparative advantage in palm oil export, mainly in these five importing countries. It can be explained because Indonesia is the largest palm oil producer in the world. The result also shows that Indonesia's highest RCA indices were recorded in Spain for the last twenty years compared to other main importing countries, followed by the Netherlands, China, India, and United States.

Table 1

Result of RCA Index, $2010-2019$

\begin{tabular}{|r|r|r|r|r|r|}
\hline \multirow{2}{*}{ Year } & \multicolumn{5}{|c|}{ RCA Index } \\
\cline { 2 - 6 } & USA & China & India & \multicolumn{1}{c|}{ Netherlands } & \multicolumn{1}{c|}{ Spain } \\
\hline 2000 & 15.16487 & 21.96363 & 22.6054 & 76.70987 & 94.50087 \\
\hline 2001 & 1.905956 & 21.33351 & 20.10934 & 70.34846 & 90.66852 \\
\hline 2002 & 5.486836 & 20.39863 & 23.72489 & 98.1346 & 112.447 \\
\hline 2003 & 0.040139 & 23.94427 & 21.31307 & 71.86922 & 86.48299 \\
\hline 2004 & 22.04869 & 30.23036 & 29.11238 & 84.07784 & 148.2191 \\
\hline 2005 & 6.867385 & 27.42385 & 34.24984 & 79.49658 & 85.61004 \\
\hline 2006 & 13.96671 & 29.51019 & 43.09908 & 87.84674 & 79.62938 \\
\hline 2007 & 13.6168 & 25.68036 & 64.96472 & 68.40674 & 69.77959 \\
\hline 2008 & 11.31061 & 28.36771 & 74.29791 & 69.45238 & 94.93269 \\
\hline 2009 & 13.85131 & 33.75273 & 34.16956 & 81.27503 & 78.62507 \\
\hline 2010 & 5.47412 & 35.2487 & 34.0945 & 82.0245 & 65.7503 \\
\hline 2011 & 3.53399 & 24.1651 & 27.0424 & 45.5384 & 75.8285 \\
\hline 2012 & 5.50206 & 33.5662 & 23.9763 & 49.5194 & 62.8889 \\
\hline 2013 & 35.7099 & 31.5662 & 21.9793 & 49.4112 & 104.310 \\
\hline 2014 & 41.6894 & 45.4439 & 20.8102 & 53.3852 & 109.332 \\
\hline 2015 & 49.8943 & 61.6815 & 18.0941 & 48.5211 & 134.831 \\
\hline 2016 & 62.5137 & 76.6969 & 21.5393 & 68.7939 & 128.032 \\
\hline 2017 & 72.7424 & 151.241 & 22.7985 & 44.2478 & 107.829 \\
\hline 2018 & 77.5187 & 144.069 & 24.0326 & 47.6689 & 93.411 \\
\hline 2019 & 82.3137 & 47.4505 & 16.8691 & 44.3792 & 113.044 \\
\hline Average & 27.05758 & 45.68671 & 29.94412 & 66.05535 & 96.8076 \\
\hline
\end{tabular}

Source: Revealed Comparative Advantage (RCA) indices

Figure 1 depicts Indonesia's palm oil export RCA index from 2000-2019 in five major importing countries. In the United States, the RCA indices initially had some fluctuation since 2000, even experience a significant decrease in 2003 with the value of 0.04 since the export value fell sharply. It can be due to the substantial decline in palm oil export. In 2003, it was the lowest value of Indonesia palm oil export to the USA. The RCA index had risen in the following years significantly at 22.04 point in 2004 since the palm oil export also increased, but then the RCA index fluctuated during 2005 - 2012. However, in 2013 the RCA index began to increase significantly from 5.50 to 35.7 and continued to whop gradually to the value of 82.21 in 2019 . Based on the Indonesia palm oil export to the US, there is a $671.61 \%$ change in palm oil export value between 2012 and 2013. So, it means that there is a high demand of palm oil in the US during $2012-2019$.

Meanwhile, in China, the RCA indices steadily rose in 2000 from 21.96 to 76.69 in 2016 and increased significantly to the highest level in 2017 to 151.24 points. Based on the Indonesia palm oil export to China, generally, the export value of palm oil showed an increase since $2000-2019$. On the other side, the export 
value of all commodities to China also escalates during the period. However, the RCA indices fell dramatically to 47.45 in 2019. This might be due to the increase of the world exports value of palm oil at $260 \%$, while the world export value of all commodities fell $3.09 \%$. Therefore, despite having an increase in palm oil export in China, but in other side, the world export value of palm oil significantly increased and the export value of all commodities from Indonesia to China also expanded in 2019, thus the RCA index decline.

In the Netherlands, Indonesia's RCA index generally decreases with several fluctuations. In 2000, the RCA index was 76.70 and reached its highest level in 2002 at 98.13 points. In the following years, the RCA index had some variations but decreased in 2011 at 45.53 points. Despite trying to escalate again in 2016 at 68.79 points, the RCA index reached its lowest level in 2019 at 44.37 points. According to the data, the Indonesia export value of palm oil to the Netherlands experienced a doubled increase in 2002 from the previous year and continued to escalate until 2012. However, it then decreases gradually from 2014 to 2019. The world export value of palm oil to the Netherlands during 2000 - 2019 was higher than Indonesia export value of palm oil to the Netherlands.

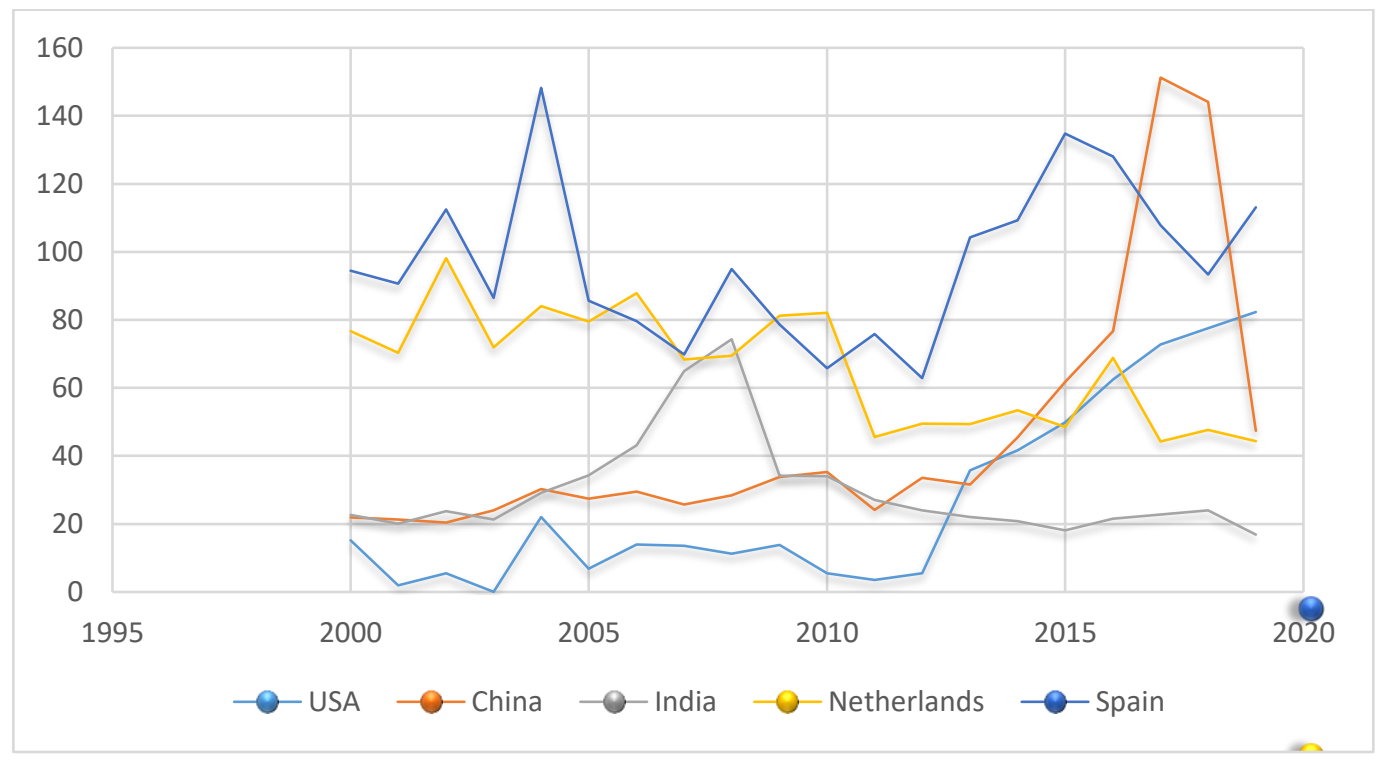

Figure 2. RCA Indices of Indonesia Palm Oil Export to Five Major Importing Countries, 2000 2019

Source: Statistics Indonesia (BPS, 2021)

In contrast with other countries, Indonesia's RCA indices in India tend to flatten, with the average was 29.94 points. In 2000 , the index was 22.60 , then it increased to 29.11 in 2004 and reached its highest level in 2008 at 74.29 points. However, the index was significantly fell to 34,16 in the following years and steadily declined to 16.87 in 2019. According to the data of Indonesia export value of palm oil, there is an increase in palm oil export in 2004 as well as in 2008. Still, the value experienced some fluctuation and tended to decrease until 2019. The low RCA index of palm oil might be due to the high value of all commodity export from Indonesia to India. Also, the world export value of palm oil to India was greater and tended to escalate during $2000-2019$.

Meanwhile, compared to other importing countries, the RCA indices in Spain show the highest value, with the RCA index average between 2000 and 2019 was 96.8. And, despite experienced some fluctuations, the RCA index tends to increase. In 2000, the RCA index was 94.5 points and reached its highest level in 
2004 at 148.21 points. Although the RCA index declined significantly in the following year and fluctuated in several years, it was noted that the RCA index hit 113.04 points in the end of 2019. The high RCA index in Spain can be explained because there is no significant difference between Indonesia export value and the world export value of palm oil in Spain, despite these two variables increase during 2000 - 2019. For instance, in 2004, where the RCA index was very high, Indonesia palm oil export value was almost $50 \%$ of the value of all commodities export.

\section{Gravity model}

In this study, the gravity model was used to analyze Indonesia's palm oil export determinants to five major importing countries with additional independent variables. Therefore, there are ten independent variables used in this model. The data consist of time series data from 2000 to 2019 and cross-section data from five major importing countries, including China, the United States, India, the Netherlands, and Spain. There are two general approaches in panel data regression, namely Fixed Effects Model (FEM) and Random Effects Model (REM)(Firdaus, 2020). In this study, Fixed Effects is the best model to be applied. Table 2 display the result of the panel data regression of Indonesia's palm oil export.

Table 2

The Estimation Result of Panel Data Analysis

\begin{tabular}{|c|c|c|}
\hline Variables & Coefficient & Probability \\
\hline C & 142.3931 & 0.1557 \\
\hline LNFDI & 0.054532 & 0.7453 \\
\hline LNGDP & 1.488879 & $0.0067^{*}$ \\
\hline NTM & 1.368879 & $0.0012^{*}$ \\
\hline BOR & -0.082287 & 0.8564 \\
\hline FTA & 1.097486 & $0.0079^{*}$ \\
\hline LANG & 0.114442 & 0.8015 \\
\hline DIS & -0.000700 & $0.0000^{*}$ \\
\hline LNER & 1.283384 & $0.0988^{* * *}$ \\
\hline INF & 0.035518 & 0.6083 \\
\hline LNPP & -9.207334 & 0.1092 \\
\hline R-Squared & 0.845044 & \\
\hline Adjusted R-Square & 0.819522 & \\
\hline Prob (F-statistic) & 0.000000 & \\
\hline
\end{tabular}

* Significant on $1 \%$ of the significance level

$* *$ Significant on $5 \%$ of the significance level

$* * *$ Significant on $10 \%$ of the significance level

Source: own calculation

Based on the data panel regression result displayed in Table 2, five independent variables significantly affect Indonesia's palm oil export to the five major importing countries. In comparison, the other five independent variables do not substantially influence Indonesia's palm oil export. Besides, the adjusted RSquared of the regression model is 0.819 , which means that the independent variables applied in this model can determine Indonesia's palm oil export by $81.9 \%$. In comparison, $18.1 \%$ is explained by other variables, which is not included in the model. Meanwhile, the F-statistics shows that the regression model is valid since the $\mathrm{p}$-value is less than 0.05 .

The basic theory used in this study is the gravity model used widely in international trade studies to analyze the determinant of trade flows. Therefore, the factors based on the gravity model included in this 
research are the economic distance, language, border between Indonesia and the importing countries, real GDP per capita of five major importing countries, and population of importing countries.

This study revealed that economic distance has a negative impact on the export. Where the farther the distance between Indonesia and the palm oil importing countries, the more commodity export value will decline. The statistical result indicates that if there is a $1000 \mathrm{~km}$ increase in distance between Indonesia and the destination countries, the palm oil export value will decrease by $0.7 \%$. According to Wardani et al. (2018), when the economic distance between the exporting and importing countries increases, it will lead to higher costs for the importing countries. Therefore, the demand for the commodity will reduce, and the export value of the origin countries will decrease. Le (2017) stated that the variable of economic distance is a proxy for shipment and transaction price. When two countries are far from each other, transportation and purchasing costs, tend to be large.

This study also found that GDP per capita has a positive and significant effect on Indonesia's palm oil export value. Based on the theory, GDP per capita indicates the purchasing power and absorptive capacity of importing countries for specific goods and services(Inayah, Oktaviani dan Daryanto, 2016). Thus, the growth of GDP per capita will raise the demand from importing countries. This study found that if there is a one per cent increase in the GDP per capita of partner countries, the export value of Indonesia's palm oil will rise $1.49 \%$. The result indicates that the GDP of partner countries is an essential variable for Indonesia's palm oil export.

Meanwhile, this study found that the population of importing countries has an insignificant impact on palm oil export from Indonesia. It is contrary to the theory, where an increase in population in the destination countries is a proxy for market size and product demand. It can be explained that the high consumption of palm oil in the importing countries might be used for manufacturing, not for individual consumption. Therefore, the population of partner countries is not an essential variable in the case of export value of Indonesia's palm oil.

Other variables derived from the gravity model are border and language. It is assumed that Indonesia and the five major importing countries do not share the same boundary. Thus, transportation costs paid by the partner countries will increase and lead to the decline of palm oil demand by the partner countries. However, this study found conversely that border and language do not have any significant impact on Indonesia's palm oil export to the destination countries.

Based on the theory, countries that speak the same language tend to have more trade. According to Hapsari dan Mangunsong (2006), the language variable is related to the information cost caused by the inability to communicate and cultural differences. However, the finding in this study indicated that language do not seem to be an essential factor in Indonesia's palm oil trade with countries which is not share the same vocabulary. Therefore, it implies that no barrier and global trade tends to be liberalized.

Besides the basic gravity model, there are also additional independent variables used in this study, such as Non-Tariff Measurements (NTMs) and Free Trade Agreement (FTA). The result shows that NTMs have a significant influence on the palm oil export of Indonesia at a 1\% of significance level. This study revealed that the variable of NTM could induce $1.37 \%$ of palm oil export from Indonesia. Theoretically, NTM is a policy measure besides the tariff policy which is implemented as a protection for the domestic market and productions in import-competing with foreign goods and services. The practice of NTM can reduce the export value and potentially cause an export loss because the NTM increases the transaction cost. According to World Trade Report (2012), several studies have been conducted to measure the effect of NTM on international trade and argued that NTM contributes to trade restrictiveness.

However, the effect of NTM is sometimes ambiguous and sensitive politically. On one side, policy or regulation is needed to decrease the market failures. Still, on another side, the domestic policy is implemented to inhibit the import from foreign competitors (Beghin, Maertens dan Swinnen, 2016).NTMs 
generally divide into technical and non-technical measures, where technical measures such as Sanitary and Phytosanitary (SPS) and Technical Barriers to Trade (TBT) are implemented mainly by the advanced countries in trade policy. Studies conducted by Sari et al (2014)found that the impact of NTM by SPS measures was positively significant on Indonesia's palm oil export. Still, in contrast, the policy of TBT and trade remedy significantly decreased the export of palm oil to the main destination countries.

NTMs used in this study was not disaggregated into specific measures. Still, data from the World Trade Organization (WTO) showed that the five major export destination countries, namely the US, China, India, Netherland, and Spain, impose the NTMs policy, including to the palm oil export from Indonesia. However, the findings in this study indicate that although the importing countries implement the NTMs policy, the export value of palm oil rises substantially. The reason can be due to because Indonesia is the main producer of palm oil in the world. Data of the palm oil export from Indonesia to the Spain, China, the United States, the Netherland, and India show that the demand for Indonesia's palm oil relatively increase in the period of 2000 until 2019. The RCA indices are also very high, indicating that Indonesia's palm oil export in these countries is very competitive.

The variable of FTA was also found significant to the export of Indonesia's palm oil to the five major destination countries at the $1 \%$ of the significance level. The estimation result explains that the free trade agreement significantly increases the export value of Indonesia's palm oil by 1.09\%. Theoretically, FTA will stimulate the export and trade between two or more participating countries by removing the barriers, including tariff and non-tariff. Data of free trade agreement in Asian Regional Integration Center (Asian Regional Integration Center, 2020)show that Indonesia was cooperated in the free trade agreement with China by ACFTA (ASEAN - People's Republic of China Comprehensive Economic Cooperation) in 2002 and with India by ASEAN - India CECA (ASEAN - India Comprehensive Economic Cooperation Agreement) in 2004. Meanwhile, cooperation between Indonesia and the United States and Indonesia and the European Union, including the Netherlands and Spain, is still under proposed in the free trade agreement since 1997 and 2015.

The impact of ACFTA on Indonesian export itself has been studied by several studies, and it is found that the ASEAN - China Free Trade Agreement stimulate export from Indonesia(Ibrahim, Permata dan Wibowo, 2010; Sheng, Tang dan Xu, 2014; Yang dan Martínez Zarzoso, 2014; Indriyani, 2016). Also, the tariff liberalization under the ASEAN - India Comprehensive Cooperation Agreement (CECA) has given a benefit to ASEAN countries since India's tariff is relatively higher than ASEAN economies(Yean dan Jia Yi, 2018).

Nevertheless, in European Union, the Crude Palm Oil import has been recommended to stop in 2021 by the parliament, including the import from Indonesia, because it has a correlation with several issues such as environment, health, and animal protection. This might explain the reason for Indonesia's palm oil export reduction in the Netherlands. Indonesian government claims the European Union is doing protectionism in trade, which leads to discrimination. However, the study conducted by Rifin (2020) suggests that although the European Union, including the Netherlands, suspends Indonesia's palm oil export, there is no significant impact on the export value of Indonesia's palm oil. Meanwhile, in India, the decline of Indonesia's palm oil export might be due to several barriers, such as the import duties and as well as tariff and non-tariff policies.

The variable of inflation is found to be insignificant on the export of Indonesia's palm oil. Inflation is said to negatively affect the export value because it causes the escalation of the price of goods and production input, leading to a rise in the cost of production. Thus, consumers are unwilling to purchase foreign goods, and a decline in the export volume occurs. However, this study found that inflation insignificantly affects the export of Indonesia's palm oil. Yee et al. (2016)argued that there is an exception for the monopoly products and branded goods. Besides, the inflation in the importing countries during this period was still under control. 
The variable of foreign FDI also has an insignificant influence on Indonesia's palm oil export. According to the theory, FDI can stimulate the import of more raw materials and intermediate goods and services that are not readily available in the countries (Keho, 2020). It indicates that the increase of multinational corporations (MNC's) in the partner countries as the host countries depend on palm oil in their productions. This study is in line with research conducted by Mohanty and Sethi (2019), which found the insignificant impact of FDI on the real export in the long run, and Magalhães dan Africano (2018) which revealed that there is no relationship between outward FDI and the export.

In addition, the result of this study shows that the exchange rate has a significant impact in Indonesia's palm oil export at $10 \%$ of the significance level. This study is related to research conducted by Kemal dan Qadir (2005), which also found that the real exchange rate affects export in the long run. Yee et al. (2016)explained that when the domestic currency is undervalued, the price of foreign goods tends to be higher than the price of domestic goods. Therefore, a foreign consumer will prefer to import goods more, and then it influences export. It can be seen from the data that over the period of 2000 - 2019, Indonesia's currencies tend to be depreciated by the currencies' of partner countries. Therefore, this study revealed that the exchange rate is an important variable of Indonesia's export value.

\section{CONCLUSION}

There are some policy implications that can be drawn based on this study. The gravity model used in this study indicates that there are no essential barriers that limit the export from Indonesia's palm oil to main destination countries. Moreover, the positive impact of the free trade agreement between Indonesia and partner countries indicated that FTA is an important factor in international trade among Indonesia and its partner countries since it creates a strong bilateral relationship between countries. Therefore, there is a need for Indonesia to strengthen its trade diplomacy with these five main importing countries, including the use of negotiation strategy at the international organization WTO forum, which allows the countries to struggle for their economic interest. Also, as the issue of banning Indonesia's palm oil export to the European Union in 2021 still arise, there is an immediate to conclude the Indonesia-European Union Comprehensive Economic Partnership Agreement (CEPA).

\section{SUGGESTION FOR FUTURE RESEARCH}

This research has several limitations, including the disaggregation of the NTMs variable. Thus, future studies can be conducted by implementing the specific NTMs policy, such as SPS, TBT, and Trade Remedy. Furthermore, other explanatory variables such as tariffs measure policy might be added to further this study's development.

\section{ACKNOWLEDGEMENT}

I would like to express my gratitude to Professor Jin-Young Chung, my instructor in the International Political and Economy course, for the guidance and support to write this article. I also would like to thank the Indonesia Endowment Fund for Education (LPDP), Ministry of Finance, Republic of Indonesia, for their support during my study. 


\section{REFERENCES}

Asian Regional Integration Center. (2020). Free Trade Agreement. https://aric.adb.org/fta-country.

Bahmani-Oskooee, M. (1986) Determinants of international trade flows. The case of developing countries. Journal of Development Economics. doi: 10.1016/0304-3878(86)90007-6.

Beghin, J. C., Maertens, M., \& Swinnen, J. (2016) Non-tariff measures and standards in trade and global value chains. Nontariff Measures and International Trade, 13-38. doi: 10.1142/9789813144415_0002.

Branson, W. H. (1981). Macroeconomic determinants of real exchange rates. National Bureau of Economic Research Working Paper Series.

Dinh, T. T. B., Nguyen, V. D., \& Hoang, M. C. (2011). Applying gravity model to analyze trade activities in Vietnam. Forum for Research in International Trade.

Firdaus, M. (2020). Aplikasi Ekonometrika dengan E-Views, Stata dan R. I. Edited by Elviana. Bogor-Indonesia: PT Penerbit IPB Press.

Hapsari, I. M., \& Mangunsong, C. (2006). Determinants of AFTA Members' trade flows and potential for trade diversion. Asia-Pacific Research and Training Network on Trade Working Paper Series, (21), 3-28.

Hinloopen, J., \& Van Marrewijk, C. (2001). On the empirical distribution of the balassa index. Weltwirtschaftliches Archiv. doi: 10.1007/bf02707598.

Ibrahim, I., Permata, M. I., \& Wibowo, W. A. (2010). The impact Of ACFTA implementation on international trade of Indonesia. Buletin Ekonomi Moneter dan Perbankan. doi: 10.21098/bemp.v13i1.384.

Inayah, I., Oktaviani, R., \& Daryanto, H. K. (2016). The analysis of export determinant of Indonesian pepper in the international market. International Journal of Scicence and Research (IJSR), 5 (11), 1856 1860. doi: 10.21275/ART20163261.

Indriyani, I. (2016). The effect of ASEAN-China free trade area (ACFTA) on Indonesia export. ETIKONOMI, 15 (2), 125 - 138. doi: 10.15408/etk.v15i2.3331.

Keho, Y. (2020). Foreign direct investment and import demand in Cote d'Ivoire. International Journal of Trade, Economics and Finance. 11(2), 24-31. doi: 10.18178/ijtef.2020.11.2.661.

Kemal, M. A., \& Qadir, U. (2005). Real exchange rate, exports, and imports movements: A trivariate analysis. Pakistan Development Review. doi: 10.30541/v44i2pp.177-195.

Krueger, A. O. (2000). NAFTA's effects: A preliminary assessment. The World Economy, 23(6), 761-775. doi: 10.1111/1467-9701.00302.

Le, T. H. (2017). Does economic distance affect the flows of trade and foreign direct investment? Evidence from Vietnam. Cogent Economics and Finance, 5(1). doi: 10.1080/23322039.2017.1403108.

Magalhães, M., \& Africano, A. P. (2018). Panel analysis of the FDI impact on international trade revisited. Notas Económicas, (45), 49-64. doi: 10.14195/2183-203X_45_3.

McDonald, B. (2009). Why countries trade. Finance and Development, 46(4), 48-49. doi: 10.4324/9780429425547-2.

Mohanty, S., \& Sethi, N. (2019). Does inward FDI lead to export performance in India? An empirical investigation. Global Business Review. doi: 10.1177/0972150919832770.

Rifin, A. (2010). The effect of export tax on Indonesia's crude palm oil (CPO) export competitiveness. Asean Economic Bulletin, 27(2), 173. doi: 10.1355/ae27-2b.

Sari, A. R., Hakim, D. B., \& Anggraeni, L. (2014). Analisis pengaruh non-tariff measures ekspor komoditi crude palm oil (CPO) Indonesia ke negara tujuan ekspor utama. Jurnal Ekonomi dan Kebijakan Pembangunan, 3 (2), 111 - 135. 
Sheng, Y., Tang, H. C., \& Xu, X. (2014). The impact of the ACFTA on ASEAN-PRC trade: estimates based on an extended gravity model for component trade. Applied Economics, 46 (19), 2251 - 2263. doi: 10.1080/00036846.2014.899676.

Wardani, M. A., Mulatsih, S., \& Rindayati, W. (2018). Competitiveness and factors affecting Indonesian food industry's export to regional comprehensive economic partnership. Etikonomi, 17 (2), 185-198. doi: $10.15408 /$ etk.v17i2.7239.

Wheeler, J. O. (2005). Geography. Encyclopedia of Social Measurement, 115-123. Elsevier. ISBN 9780123693983. doi: 10.1016/B0-12-369398-5/00277-2.

Yang, S., \& Martínez, Z. I. (2014). A panel data gravity analysis of trade creation and diversion effects. China Economic Review, (29).

Yean, T. S., \& Jia Yi, A. K. (2018). Reassessing the impact of the asean-India free trade agreement. Celebrating the Third Decade and Beyond: New Challenges to ASEAN-India Economic Partnership, 48(2), 53-73. doi: 10.4324/9781351013598.

Yee, L. S., WaiMun, H., Zhengyi, T., Ying, J. L., \& Xin, K., K. (2016). Determinants of export: empirical study in Malaysia. Journal of International Business and Economics, 4(1), 61-75. doi: 10.15640/jibe.v4n1a6.

Yulismi, Y., \& Siregar, H. (2015). Determinant factors of lndonesia palm oil export to major importing countries: An error correction model analysis. Economics and Finance in Indonesia, 55(1), 65. doi: 10.7454/efi.v55i1.109. 